\title{
Analysis of ISO 9001:2015 certification readiness of JP-Graha product of Jasaraharja Putera using gap analysis
}

\author{
Bambang Purwanggono ${ }^{1 *}$, Arfan Bakhtiar ${ }^{1}$, Rifky Rahman $\mathrm{H}^{1}$, \\ ${ }^{1}$ Industrial Engineering Department Faculty of Engineering, Diponegoro University, \\ Jl. Prof. Soedarto, SH, Undip Tembalang Campus, Semarang, Indonesia 50275
}

\begin{abstract}
The fierce competition of global economy requires company to have a good Quality Management System (QMS). Efforts done by the company included applying standards of Quality Management System (QMS) ISO 9001. ISO 9001 is a standard that contains requirements of quality management system, published by the International Organization for Standarization (IOS). The object of this research is JPGRAHA PT Jasaraharja Putera. JP-GRAHA is one of the product from PT Jasaraharja dealing with fire insurance. JP-GRAHA already implemented ISO 9001:2008. But the implementation of ISO 9001:2008 suffer from a decline in consistency, meanwhile the company must prepare to upgrade into ISO 9001:2015. This research aims to identify the readiness of the company in the facing Certification of ISO 9001:2015 and provide recommendations to improve the readiness of the company. The method used in this research is Gap Analysis to evaluate current company state and assess the readiness of the company in facing certification of ISO 9001:2015. Gap Analysis is a checklist made based on the existing requirements icluded in ISO 9001:2015. The results from the calculation using the checklist will show how the readiness of JP-GRAHA PT Jasaraharja Putera in light of performing certification of ISO 9001:2015
\end{abstract}

\section{Introduction}

Insurance currently holds a very important role in providing certainty of protection or even protection for people in terms of commercial and non-commercial use. Insurance can provide protection in the form of education, health, pension, death and wealth. One of the needs in life vital in this globalization era is the need for insurance services. This encouraged the rapid spread of insurance companies as well as causing people to worry over their life insurences. Based on this fact, a lot of new insurance companies offer various types of policy in accordance to community's needs. PT. Jasaraharja Putera took part in the

\footnotetext{
*Corresponding author: b.purwanggono@gmail.com
} 
insurance loss field and was established on $6^{\text {th }}$ of June 1996. Pt Jasaraharja is a subsidiary of PT Jasaraharja. Currently PT Jasaraharja Putera have 15 leading products including JP Graha or fire insurance. JP Graha is a fire insurance product intended for wealth protection. Whether it is a house, office, shop, or factory suffer losses or damages due to fire or other events covered by the policy. Properties eligible for JP Graha insurance included building, machine, stock, furniture, and its contents. As one of the leading products from PT Jasaraharja Putera, JP Graha is required to have a good Quality Management System (QMS) to be able to improve customer satisfaction and trust. One way to meet this demand is by applying ISO 9001 concerning quality management.

There are some differences between the ISO 9001: 2015 and previous version. The newest and most prominent difference in ISO 9001:2015 is the explisit requirements of risk-based thinking to support and improve understanding and application in the process approach that already existed on the previous version of ISO 9001. Risk is the effect of uncertainty on the expected results and the concept of risk-based thinking is always implied in the requirements article of ISO 9001:2015. This international standard makes risk-based thinking more explicit and it is realized in the requirements for establishment, implementation, maintenance and continuous improvement of the quality management system. JP Graha received Certification of ISO 9001 year 2000 version since $5^{\text {th }}$ of November 2007 from SAI GLOBAL Certification Organization. Then JP Graha upgraded to ISO 9001 year 2008 risk-based thinking on $29^{\text {th }}$ of September 2010. Many advantages have been felt by PT Jasaraharja Putera on the JP Graha product after applying ISO 9001. Including increased work efficiency in operational level, process and documentation is done effectively causing the work to be consistent, performance reviewed regularly and focused on target achievement, consumer trust rose and well maintained, as well as improvement of the organization's bargaining position in market competition.

PT Jasaraharja Putera suffer from a decline of consistency in applying ISO 9001:2008. This is caused by a few things, including the process of implementing ISO 9001 is quite complicated. Meanwhile, the company must prepare to upgrade to ISO 9001:2015 because ISO 9001:2008 will expire in September 2018. This causes the company difficulties in identifying readiness of the ISO 9001 upgrading process. Based on this background, the author is interested to research the readiness of JP Graha product from PT Jasaraharja Putera in upgrading ISO 9001:2008 toISO 9001:2015. This research uses gap analysis. Gap Analysis is a comparison of actual performance with potential or expected performance. In this research the author tries to compare processes done by PT Jasaraharja Putera with JP Graha in applying ISO 9001:2008 and the conditions needed in the Certification of ISO 9001:2015. So through gap analysis the author may provide the level of readiness of the company in Certification of ISO 9001:2015 and provide suggestions and recommendations to the company to increase level of readiness in the certification of ISO 9001:2015.

\section{Overview}

\subsection{Definition of ISO 9001}

ISO standard is a standard containing requirements related to quality management system published by IOS (International Organization for Standarization). ISO 9001 is the standard management requirement and not a standard product specification. As a standard management requirement, the contents of ISO 9001 is a series of requirement articles 
ensuring consistency of management process related to the quality in a system. Articles in ISO 9001 contain what must be done by the organization to implement and build each organization management system which grow into a management system elaborating how to perform a series of activities that becomes a specific requirement on each organization [1].

\subsection{Quality Management System ISO 9001:2015}

Renewal of ISO 9001:2015 comes with a completely different focus from the previous version that contains too many documents and forms. ISO 9001:2015 no longer question documents as much, instead it focuses on the company performance using a risk-based thinking approach and the concept of Plan - Do - Check - Action is applied at all levels of the organization [2]. This is evident by several things [3]:

1. "6 compulsory procedures" term is eliminated

2. There is no separation between the procedure and form. Both are now called documented information. This means one is represented by the other.

3. Owning a Quality Manual is now not a requirement, ISO 9001:2015 also no longer dependent on management representative considered as the only one most responsible for implementing ISO 9001. Now every part is responsible for each of their portion.

\subsection{Principles in ISO 9001:2015}

The quality management system of ISO 9001 : 2015 revisions have some significant changes and one of them is a change in principles of quality management from 8 to 7 the principles of quality management [4]: Customer Focus, Leadership, Involvement of people, Process Approach, Improvement, Decisions based on evidence and Relationship Management.

\subsection{Gap Analysis}

Gap analysis is defined by IT Infrastructure Library (ITIL) as an activity that compare two kinds of data and identify their differences. Gap Analysis is normally used to compare a set of conditions. Gap analysis is generally structured on a set of field, topic or category, making the gap analysis efficient in knowing the sector that need to be repaired. Gap Analysis is effective because the checklist is structured and in accordance with the subject. Checklist will include all existing requirements and created in the form of hierarchy in its assessments, this will include common questions and provides an overview of the topics or categories that will be assessed. Questions in the checklist is made in detail and make an evaluation of each individual requirement if required. Each question related to other questions to ensure searchability [5].

The following are steps in the gap analysis:

a. Determination of Score

The Score used in gap analysis is shown in Table 1.

b. Checklist Assessment

Checklist assessment by respondents based on the current condition of organization. Respondents are selected by competence. Assessmentsis based on the terms of the scoring described in the Table 1.

c. Gap Assessment 
Assessment of gap aims to see how big of a gap is in the company. The percentage is obtained through the sum of score per variable and divided by the maximum value on the variable. The smaller the gap the better. The percentage represent company readiness in the implementation of ISO 9001:2015. Table 2 shows the range of gap value [6]:

Table 1. Score Gap Analysis

\begin{tabular}{cl}
\hline Score & \multicolumn{1}{c}{ Understanding } \\
\hline 1 & $\begin{array}{l}\text { If the organization or the company does not understand what is } \\
\text { required and does not do it. }\end{array}$ \\
2 & $\begin{array}{l}\text { If an organization or company understand the importance of the } \\
\text { activity but does not do it. }\end{array}$ \\
3 & $\begin{array}{l}\text { If the organization or the company have the documents but have not } \\
\text { implemented or have implemented but not recorded. }\end{array}$ \\
4 & $\begin{array}{l}\text { If an organization or company do the activity albeit inconsistently. } \\
\text { If an organization or company do the activity consistently. }\end{array}$
\end{tabular}

Table 2. Range Gap Analysis

\begin{tabular}{ll}
\hline Percentage & \multicolumn{1}{c}{ Illustration } \\
\hline $75 \%-100 \%$ & $\begin{array}{l}\text { The organization is ready to complete the QMS ISO 9001:2015 and } \\
\text { undertake certification. }\end{array}$ \\
$50 \%-74 \%$ & $\begin{array}{l}\text { The organization must still improve the QMS for the preparation of ISO } \\
9001: 2015\end{array}$ \\
$1 \%-49 \%$ & $\begin{array}{l}\text { QMS of the organization needs much improvement due to vast differences } \\
\text { from the Quality Management System ISO 9001:2015. }\end{array}$ \\
\hline
\end{tabular}

\section{Methodology}

\subsection{Research Method}

The research is done in PT Jasaraharja Putera branch in Semarang as the branch that acquired ISO 9001 on the product JP Graha, located in J1 Imam Bonjol no. 151 Semarang. The implementation of this research started on October 2017 until finished.

The method used in this research is gap analysis. Gap analysis aims to understand current situation and compare it with expected situation. In this research the point of reference for comparison is ISO 9001:2015. The current condition data is obtained by performing internal audit checklist ISO 9001:2015 to responsible responsible in PT Jasaraharja Putera Semarang. Including the head of the branch, Vice Head of the branch, and Human Resources Working Committee. Data on the condition is also obtained by performing direct observation to the quality system documents made by the company. The obtained data then weighted with a score of 1-5 with each percentage score presenting specified range of readiness of the company. The results then became a base to improve the readiness of the company in facing the Certification of ISO 9001:2015 and prioritized according to lowest percentage, level of ease and the scope of effect produced.

\subsection{Identification of Research Variables}


Research variables used in this research is taken from the clause included in ISO 9001:2015, the clause that become a variable is only clause 4 to clause 10 .

\section{Results and Discussion}

\subsection{Data Collection}

Primary data is obtained through observation on field. In this research primary data is in the form of system observation and internal audit checklist ISO 9001:2015 which are made to understand the condition of company readiness for certification. There are 3 people who become respondents and they are selected for this portion because of their significant involvement in Quality Management System JP-GRAHA PT Jasaraharja Putera.

\subsection{Data Processing}

Data processing at this stage is to calculate the scores obtained from the internal audit checklist. The results of score calculation will then be used as the basis for identifying level of readiness of the company in facing the Certification of ISO 9001:2015. The total score for each variable from the results of the checklist are Organization Context $(80 \%)$, Leadership (84\%), Planning (75\%), Support (81\%), Operations (80\%), Performance Evaluation (85\%), and Improvement (83\%).

\subsubsection{Checklist Result Analysis of the Organization Context Clause}

After gap analysis is performed in the company for the organization context, a value of $80 \%$ is obtained. Organization Context Clause Recap are 4.1 Understand the organization and its context (80\%), 4.2 Determine the scope of quality management system (77\%), 4.3 Quality management system and its processes (90\%), 4.4 Quality management system (QMS) and its processes (73\%) and Readiness Value (80\%).

\subsubsection{Checklist Result Analysis of the Leadership Clause}

After gap analysis is performed in the company for the leadership, the value of readiness obtained is $84 \%$ The value on each point has exceeded 75 percent which indicates that the company is ready to do certification in terms of leadership. Table 5 below shows the results of gap analysis performed on the leadership clause. Leadership Clause Recap are 5.1 Leadership and commitment (86\%), 5.2 Policies (85\%), 5.3 Role of the organization, responsibility and authority (80\%) and Readiness Value $84 \%$.

\subsubsection{Checklist Result Analysis of the Planning Clause}

There are 3 sub-clauses in clause 6.1 planning. Namely : 6.1 Actions to deal with risks and opportunities, 6.2 Quality objectives and plans to achieve it, and 6.3 Planning changes. There is 1 sub-clause that is under the standard value, namely sub-clause 6.1 Actions to deal with risks and opportunities. So the company needs to pay attention and perform improvement on this sub-clause. Planning Clause Recap are 6.1 Actions to deal with risks and opportunities (60\%), 6.2 Quality objectives and plans to achieve it (86\%), 6.3 Planning Changes (80\%) and Readiness Value (75\%).

\subsubsection{Checklist Result Analysis of the Support Clause}

There is no sub-clause with a value under $75 \%$. The following is an analysis for each subclause on clause 7. Support Clause Recap are 7.1 Resources (79\%), 7.2 Competencies 
(85\%), 7.3 Awareness (80\%), 7.4 Communication (80\%), 7.5 Information documented $(82 \%)$ and $81 \%$.

\subsubsection{Checklist Result Analysis of the Operational Clause}

The compancy has performed activities on this clause good enough, but it still needs some improvement because there are some sub-clauses with value below standard. The following is an analysis for each sub-clause on Operational clause. Operational Clause Recap are 8.1 Planning and control of operations (90\%), 8.2 Requirements for the products and services (85\%), 8.3 Design and development of products and services (69\%), 8.4 External products and services control (8.5), Production and service provision (84\%), 8.6 Release of product and service (70\%), 8.7 Control over output that does not match (83\%) and Readiness Value $(80 \%)$.

\subsubsection{Checklist Result Analysis of the Evaluation Clause}

There are no sub-clause below the standard value. This shows that the implementation of this clause is good enough. The following is an analysis for each sub-clause on Evaluation clause. Evaluation Clause Recap are 9.1 Monitoring, measurement analysis and evaluation (85\%), 9.2 Internal Audit (88\%), 9.3 Management Overview (82\%) and Readiness Value $(85 \%)$.

\subsubsection{Checklist Result Analysis of the Improvement Clause}

There is no sub-clause with value under $75 \%$ on this clause. The following is an analysis for each sub-clause on Improvement clause. Improvement Clause Recap are 10.1 General (88\%), 10.2 Incompatibility and repair actions (78\%) and Readiness Value (83\%)

\subsection{Recommendations}

Based on the results on section 4.2, it is known there is some clause that has low value of readiness in light of preparation for the Certification of ISO 9001:2015 which require improvements. The following is recommendations concerning the clauses with low readiness value:

Table 3. Recommendations

\begin{tabular}{|c|c|}
\hline Clause & Improvement \\
\hline $\begin{array}{l}\text { 4.2 Determine the } \\
\text { scope of the quality }\end{array}$ & $\begin{array}{l}\text { The company must clearly define the boundaries of what is } \\
\text { inside the scope of QMS }\end{array}$ \\
\hline $\begin{array}{l}\text { management } \\
\text { system }(\mathrm{QMS})\end{array}$ & $\begin{array}{l}\text { Create documents related to the scope of QMS because this } \\
\text { document is also prerequisite of ISO } 9001: 2015\end{array}$ \\
\hline $\begin{array}{l}4.3 \text { QMS and its } \\
\text { processes }\end{array}$ & $\begin{array}{l}\text { The company needs to clearly define the risk and } \\
\text { opportunities of every business process }\end{array}$ \\
\hline 5.3 Roles of & Top management of the company especially Quality \\
\hline $\begin{array}{l}\text { companies, } \\
\text { responsibility and } \\
\text { authority }\end{array}$ & $\begin{array}{l}\text { Management Repressentative (QMR) start to Adjust and } \\
\text { ensure all processes on the Quality Management System are } \\
\text { in accordance with the needs of ISO 9001:2015 and perform } \\
\text { repairs or adjustments if there are incompatibilities. QMR } \\
\text { should also form a small team in preparation for the } \\
\text { Certification of ISO 9001:2015 }\end{array}$ \\
\hline 6.1 Actions to deal & Risk and opportunities must be clearly defined for all \\
\hline
\end{tabular}


with risks and opportunities

\subsection{6 company} knowledge

\subsection{Documented Information}

\subsubsection{Input design} and development

\subsubsection{Control design and development 8.3.6 Change in design and development}

\subsubsection{Types and control level}

8.6 Release of product and services process

Add one division on the organizational structure of the company which is the risk management division The company will need to implement and integrate risk management into quality management system and evaluate its effectiveness

The company should create documents related to risks and opportunities although is not prerequisite to ISO 9001:2015. But this document may become a source of information about what is considered and what has been done. This document will also facilitate the audit process Continue to update company knowledge, in terms of written knowledge such as standards, results of their discussions with customers, discussions with academics, the company should archive this information to make it easily accessible. For internal knowledge can inferred from an expert who works at the company, experience from failures and others Matching documents and records currently used by the company to be the documented information in accordance with the needs of ISO 9001:2015.

The company will need to make documented information in the form of input recording of the design and development because it is a prerequisite of ISO 9001:2015

The company will need to make documented information in the form of the activity of the control of design and development recording Improve the consistency of the company in the reviewing and identifying changes during or after the development is done.

The company will need to make documented information in the form of changes in design and development recording Ensure that all external parties who have impact on the company is in the scope of control of the Quality Management System (QMS) by performing periodic evaluation on external parties.

The company will need to make the documented information in the form of compliance recording

Changing the company internal audit sheet with the ISO 9001:2015 internal audit sheet

Maintain and improve the consistency of the company in conducting periodic internal audit

10.2Incompatibility Immediately change QMS ISO 9001:2008 into QMS ISO and repair actions 2018

\section{Conclusions}


Based on the results of thorough gap analysis on the product JP-GRAHA PT Jasaraharja Putera concerning readiness for certification of ISO 9001:2015, the company has value readiness of $80 \%$. This shows that the company is of category $1(75-100 \%)$ namely the company or organization is ready to do QMS ISO 9001:2015 and undertake certification.

There are several improvements that can be done by JP-GRAHA PT Jasaraharja Putera to improve readiness in facing certification of ISO 9001:2015. The improvement can be seen in details on table 13 to table 18 .

\section{References}

[1] S. L. Prabowo, "Implementasi Sistem Manajemen Mutu (ISO:9001:2008) di Perguruan Tinggi,” Guideliness IW A-2, 2009.

[2] V. Gasperz, “Total Quality Management," PT. Gramedia Pustaka Utama, 2001.

[3] L. Ibrohim, "ISO 90012015 FDIS Penjelasan Klausul- Klausul.," PT. Gunastara, 2015 .

[4] A. Parakarsa, N. Setyanto dan L. kusuma, "Analisis Penerapan Sistem Manajemen ISO 9001:2008 Menggunakan Gap Analysis Tool (Studi kasus PT. Sahabat Rubber Industries, Malang)," Jurnal Rekayasa dan Manajemen Sistem Industri, 2015.

[5] M. Picard, A. Renault, B. Barafort dan S. Cortina, "Measuring readiness for compliance: A gap analysis tool to complete the TIPA process assessment framework.," Springer international publishing Switzerland, Vol. \%1 dari \%2633(2016),106-116, 2016.

[6] A. Bakhtiar dan B. Purwanggono, "Analisis Implementasi Sistem Manajemen Kualitas ISO 9001 : 2000 dengan menggunakan GAP Analysis Tools (Studi Kasus PT. PLN (PERSERO) PILITRING JBN Bidang Perencanaan )," Jurnal Teknik Industri Undip, 2009. 